\title{
Cell Culture of Rainbow Trout Liver
}

\author{
Tasuku Watanabe,* Masanori Nakano,* Hiroyoshi Asakawa,* \\ and Tadaaki Moritomo*
}

(Accepted July 26, 1986)

\begin{abstract}
The primary cultures of rainbow trout fry live $i$ cells were performed in TC199 medium supplemented with $10 \%$ fetal bovine serum and with $10 \mathrm{ng} / \mathrm{ml}$ of epidermal growth factor (EGF) and/or $40 \mathrm{nM}$ of insulin. Epithelial cells grown in a flask supplemented with EGF and insulin, designated RTL-4, could be transferred at the 40th day of the primary culture and have been subcultured 40 times. The cells got fast doubling time gradually, and were able to be transferred at intervals of 7-10 days. RTL-4 cells grow in the manner of contact inhibited monolayer and consist of large epithelial cells with a round nucleus and abundant granular organella. Electron microscopically, most of the cells were large and round with a round nucleus having a large electrondense nucleolus at the center of nucleus and had well developed rough surfaced endoplasmic reticulum and mitochondria which are the principle morphological properties of liver cells. Some of the cells were weakly PAS positive. RTL-4 cells had as high a susceptibility to IPNV as that of SE-A10 cells, when examined by plaque assay. And the cells had a tenth or less susceptibility to IHNV than that of SE-A10 cells.
\end{abstract}

Many cell lines have been established from fish tissues for the prupose of the detection and isolation of fish viruses, ${ }^{\text {i) }}$ since the establishment of rainbow trout Salmo gairdneri gonadal cells line, RTG-2, by Wolf and Quimby, ${ }^{2)}$ which is the first permanent cell line of fish origin. But, there have been few studies on the development of the fishoriginated tissue cultures which have the differentiated functions of derived tissue cells. In mammals, many studies on functional cell cultures have been performed for investigating cell genetics, cell differentiation, malignant transformation, or cell metabolisms.. ${ }^{3,4}$ Recently, Hayashi and Ooshiro investigated gluconeogenesis by using the primary culture cells derived from Japanese eel Anguilla japonica liver and found that cultured eel liver cells had the higher activity of glycogen and protein synthesis than freshly isolated liver cells."

We tried to establish a cell line which had a differentiated liver function of rainbow trout by using mammalian growth factors which are known to be effective to epithelial cell cultures. ${ }^{8)}$ In those studies, some transferable tissue culture cells which had epithelial cell monolayer morphology were obtained. This report describes the early cultivations of rainbow trout liver cells, the effect of growth factors, and some properties of transferable cultures.

\section{Materials and Methods}

\section{Fish, Cell Culture, and Viruses}

About 3-month-old rainbow trout fry $(2.6-3.5 \mathrm{~g}$ of body weight and $6.5-7.5 \mathrm{~cm}$ of body length) were obtained from Yamaguchi Trout Farm, Yamanashi, and were stocked in a small aerated tank circulating the water for a few weeks at $15^{\circ} \mathrm{C}$ until use.

Chum salmon Oncorhynchus keta embryonated cell line, $\mathrm{SE}^{\mathrm{T}}{ }^{\text {) }}$ and epithelial clone of SE, SEA10, were used in this study. Cells were grown and maintained in Eagle's minimum essential medium (MEM) supplemented with $10 \%$ fetal bovine serum (FBS) and $100 \mu \mathrm{g} / \mathrm{m} l$ of kanamycin sulfate (MEM-10).

Infectious pancreatic necrosis virus, IPNV, ${ }^{p)}$ isolated from a rainbow trout, and infectious hematopoietic necrosis virus, IHNV, ${ }^{10)}$ isolated from a Yamame $O$. masou, both of which were described in previous paper, ${ }^{11}$ were prepared by infecting the monolayer cultures of SE cells propagated at $15^{\circ} \mathrm{C}$.

\section{Primary Culture}

Rainbow trout fry were dipped in the water containing $100 \mathrm{I} . \mathrm{U} / \mathrm{m} l$ of penicillin $\mathrm{G}$ potassium for $24 \mathrm{~h}$. After anesthesized in $100 \mathrm{ppm}$ tricaine methane sulfonate (Crescent Res. Chem. Inc., AZ,

* Department of Veterinary Science, Nihon University, Kameino, Fujisawa 252, Japan (渡連 翼, 中野雅功, 浅川洋美, 森友忠昭: 日本大学震韵医学部). 


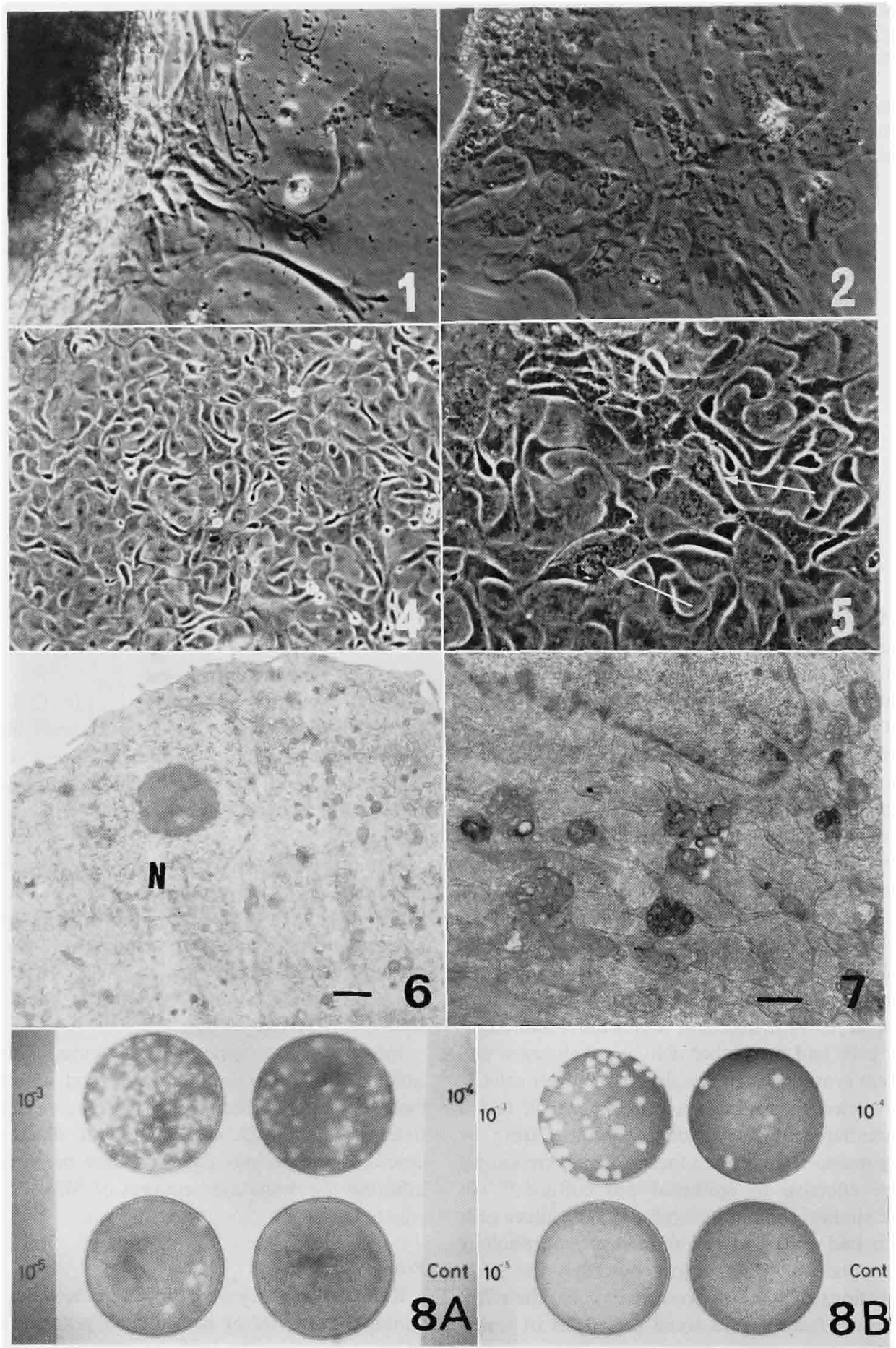

Figs. 1, 2, 4, 5. Phase contrast photomicrographs.

Fig. 1. Migration of epithelial cells and fibroblastic cells from a planted fragment of rainbow trout liver at the 7th day of primary cultrue.

Fig. 2. Colony of epithelial cells in the primary culture flask of RTL-4, 40 days after its initiation. 


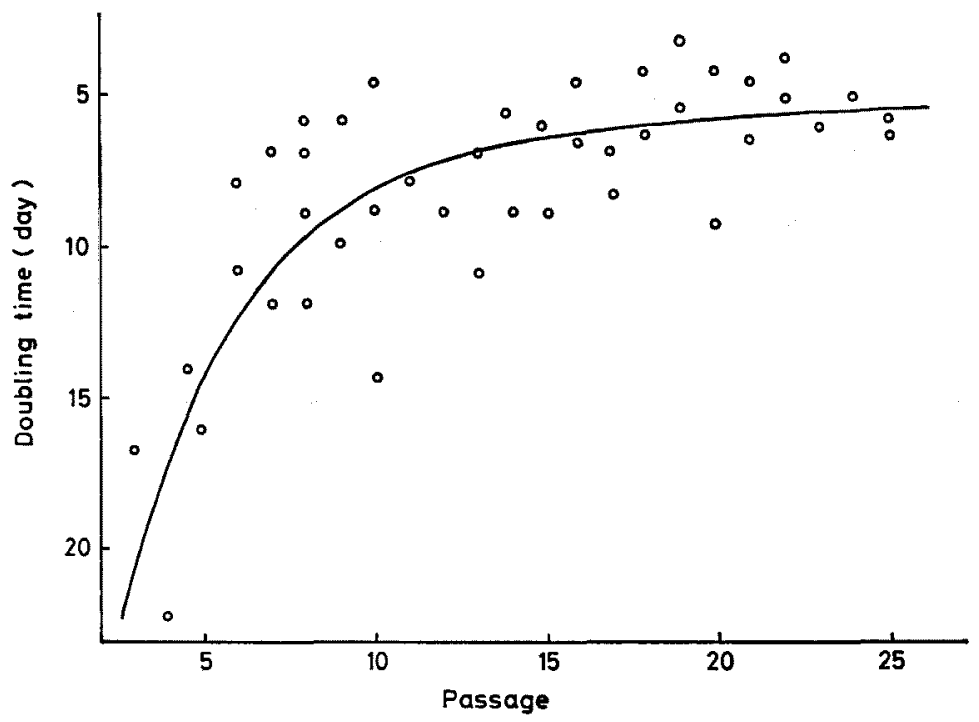

Fig. 3. Growth curve of RTL-4 cells from 2 nd passage to 25 th passage at the cultivation density of $1-3 \times 10^{5}$ cells per flask.

USA) solution, disinfected the surface of abdormen with $70 \%$ ethyl alcohol, laparotomized, liver was transferred in a sterilized glass dish and minced into small fragments with scissors in small amount of TC199 medium supplemented with $10 \% \mathrm{FBS}$ and containing $200 \mathrm{I} . \mathrm{U} . / \mathrm{ml}$ of penicillin, $200 \mu \mathrm{g} / \mathrm{m} l$ of streptomycin sulfate, and $30 \mathrm{I} . \mathrm{U} . / \mathrm{m} l$ of mycostatin. The cells and fragments were suspended in the TC199 medium with $10 \%$ FBS $(199-10)$ at the density of $10^{5}$ cells per $\mathrm{ml}$, transferred into $25 \mathrm{~cm}^{2}$ plastic tissue culture flasks (Corning Glass Work, NY, USA), and cultivated at $20^{\circ} \mathrm{C}$. The half of the medium was exchanged twice a week for the whole period of primary culture. Seven fish were used for primary culture. Each flask was designated RTL- and supplemented with $10 \mathrm{ng} / \mathrm{m} l$ of mammalian epidermal growth factor (EGF: Biomed. Technol. Inc., MA, USA) and/or $40 \mathrm{nM}$ of insulin (Sigma,
MO, USA) as described by Richman et al. ${ }^{\text {g) }}$ Table 1 shows the flask number and the supplementation of EGF and insulin.

\section{Cell Growth}

When cells were grown to form a confluent monolayer cell sheet, cells were trypsinized, counted, and reseeded at the density of $1-3 \times 10^{5}$ cells per flask. The doubling time (D. T.) was calculated from the following formula in which $\mathbf{N}_{0}$ is the cell numbers seeded, $\mathrm{N}$ the cell numbers counted, and $t$ the days for confluent cell sheet.

$$
\text { D.T. }=\mathrm{t} \log 2 /\left(\log \mathrm{N}-\log \mathrm{N}_{0}\right)
$$

\section{Morphology of Cells}

Flasks seeded with rainbow trout liver cells were observed daily with a phase contrast tissue culture microscope. Occasionally, cells cultivated on cover slips for $24 \mathrm{~h}$ at $20^{\circ} \mathrm{C}$ were fixed with

Fig. 4. Monolayer cell sheet of RTL-4 cells at 40th passage, consisting of large epithelial cels and a few fibroblastic spindle-shaped cells.

Fig. 5. High magnification of Fig. 4, showing large epithelial cells with a round nucleus and granular intracytoplasmic organella around a nucleus (arrows).

Fig. 6. Electron microphotograph of RTL-4 cells, showing a typical round nucleus (N) at the edge of the cell with a large electron-dense nucleolus and smooth cell surface. Scale bar is $1 \mu \mathrm{m}$.

Fig. 7. Electron photomicrograph of RTL-4 cells, showing expanded well-developed rough surfaced endoplasmic reticulum. Scale bar is $500 \mathrm{~nm}$.

Fig. 8. Plaque formation of salmonid fish viruses on RTL-4 cells stained with Giemsa at the 8th day (IPNV: A) and 10th day (IHNV: B) of inoculation. The numbers at each side of dishes show the dilutions of viruses. 
Table 1. Effects of two growth factors on the primary culture of rainbow trout liver cells

\begin{tabular}{|c|c|c|c|c|c|c|c|}
\hline \multirow{2}{*}{$\begin{array}{c}\text { Flask } \\
\text { No. }\end{array}$} & \multicolumn{2}{|c|}{ Fish used } & \multicolumn{2}{|c|}{ Supplementation of } & \multirow{2}{*}{ - Morphology } & \multirow{2}{*}{$\begin{array}{l}\text { Period of } \\
\text { primary } \\
\text { culture }\end{array}$} & \multirow{2}{*}{ Passage } \\
\hline & B.W. (g) & B.L. (cm) & $E G^{1)}$ & Insulin ${ }^{2)}$ & & & \\
\hline RTL-1 & 2.65 & 6.5 & + & + & Flbroblastic & 50 days & - \\
\hline RTL-2 & 2.50 & 6.4 & - & + & Epithelial & 70 & - \\
\hline RTL-3 & 3.54 & 7.5 & + & - & Fibroblastic & 50 & - \\
\hline RTL-4 & 2.69 & 6.7 & + & + & Epithelial & 40 & 40 \\
\hline RTL-5 & 3.02 & 7.0 & - & + & $N^{3}{ }^{3}$ & - & - \\
\hline RTL-6 & 2.63 & 6.9 & + & - & NG & - & - \\
\hline RTL-7 & 2.69 & 6.8 & - & - & Fibroblastic & 81 & 2 \\
\hline
\end{tabular}

1) EGF: Mouse epidermal growth factor, $10 \mathrm{ng} / \mathrm{m} /$.

2) Insulin: Bovine insulin, $40 \mathrm{nM}$.

3) NG: No growth was observed.

methyl alcohol and stained with Giemsa solution. For glycogen accumulation study, cells cultivated on cover slips with 199-10 supplemented with $0.1 \%$ glucose for a week were fixed with Carnoy solution and stained with periodic acid Schiff (PAS) solution and Mayer's hematoxylin.

\section{Electron Microscopy}

Cells cultivated in a $150 \mathrm{~cm}^{2}$ tissue culture flask were trypsinized, resuspended in 199-10, and fixed with adding the equal volume of $5 \%$ glutaraldehyde in $0.1 \mathrm{M}$ phosphate buffer ( $\mathrm{pH} 7.3$ ) for $2 \mathrm{~h}$ at $4^{\circ} \mathrm{C}$. After concentrated by centrifuging at $1,500 \mathrm{rpm}$ for $15 \mathrm{~min}$, cells were postfixed with $1 \% \mathrm{OsO}_{4}$ in phosphate buffer, then, dehydrated in graded alcohols, embedded in EPOK812, and prepared for ultrathin sections. Sections were stained with uranyl acetate and lead citrate, and examined with a JEM1200EX electron microscope.

\section{Virus Infectivity}

Plaque assay for salmonid fish viruses described previously $^{8)}$ was performed. Briefly, monolayer cell sheets formed on Falcon 3002 plastic tissue culture dishes were pretreated with $5 \mu \mathrm{g} / \mathrm{m} l$ polyblene $^{12)}$ (Aldrich, WIS, USA) at $20^{\circ} \mathrm{C}$ for $30 \mathrm{~min}$. Then, cells were inoculated with diluted virus solutions at $15^{\circ} \mathrm{C}$ for $1 \mathrm{~h}$. The cells were overlayed with $8 \mathrm{ml}$ of MEM-10 supplemented with $0.5 \%$ agarose, cultivated at $15^{\circ} \mathrm{C}$ for $7-10$ days, and were fixed with formalin and methyl alcohol, and stained with Giemsa solution.

\section{Results}

\section{Primary Culture of Rainbow Trout Liver Cells}

Seven primary cultures were performed. As shown in Table 1, EGF and insulin were added into two flasks (RTL-1 and RTL-4), EGF into two (RTL-3 and RTL-6), insulin into two (RTL-2 and RTL-5), and non of them was added into a flask, RTL-7. In 5-7 days of primary cultures, fibroblastic cells and epithelial cells were observed to migrate from tissue fragments (Fig. 1) in every flask. Those cells grew slowly except RTL-5 and RTL-6 to form cell colonies in several places of the flasks. Cell growth was not observed in the flasks of RTL-5 and RTL-6. Epithelial cells grew dominantly in two flasks (RTL-2 and RTL-4). Fibroblastic cells had been predominant in three flasks (RTL-1, RTL-3, and RTL-7). RTL-2 grew very slowly, stopped the growth, and became extinct at the 70th day of primary culture. As shown in Fig. 2, RTL-4 cells grew to form many colonies of epithelial cells in the 40th day of primary culture, and were trypsinized and reseeded in two newly prepared flasks.

\section{Passage of RTL-4}

Secondarily passaged RTL-4 cells had a epithelial morphology and grew to form a monolayer cell sheet until contact inhibition restricted the growth. Since the secondary culture, as shown in Fig. 3, RTL-4 cells got fast doubling time gradually, and, after the tenth passage, were able to be transferred at the intervals of 7-10 days when seeded at the density of $3 \times 10^{5}$ cells per flask. After 10th passage the cells were cultured with EGF- and insulin-free MEM-10 and grew rapidly without any alternation of morphology. The cells were subcultured for 40 times until June, 1986.

\section{Morphology of RTL-4}

RTL-4 cells grew in the manner of contact inhibited monolayer until the formation of confluent cell sheets (Fig. 4). The saturation density of the cells was $4.8-5.2 \times 10^{4}$ cells $/ \mathrm{cm}^{2}$. The cells 
Table 2. Comparison of plaque formation of fish virueses between SE-A10 and RTL-4

\begin{tabular}{|c|c|c|c|}
\hline \multirow{2}{*}{ Virus } & \multirow{2}{*}{$\begin{array}{l}\text { Virus } \\
\text { dilution }\end{array}$} & \multicolumn{2}{|c|}{$\begin{array}{c}\text { Virus titer } \\
\left(\times 10^{3} \mathrm{PFU} / \mathrm{m} l\right)\end{array}$} \\
\hline & & SE-A10 & RTL-4 \\
\hline \multirow[t]{4}{*}{ IPNV } & $10^{-3}$ & Confluent ${ }^{12}$ & Confluen \\
\hline & $10^{-4}$ & 28 & 14 \\
\hline & $10^{-5}$ & 30 & 20 \\
\hline & Mean & 29 & 17 \\
\hline \multirow[t]{4}{*}{ INHV } & $10^{-3}$ & 15 & 2.0 \\
\hline & $10^{-4}$ & 15 & 1.0 \\
\hline & $10^{-5}$ & 25 & $-2)$ \\
\hline & Mean & 18 & 1.5 \\
\hline
\end{tabular}

1) Too many plaques were formed confluently to count the numbers of plaques.

2) No plaque was formed.

consisted of large epithelial cells with a round or oval nucleus and abundant granular intracytoplasmic organella around nuclei suspected to be mitochondria (Fig. 5). A few fibroblastic spindleshaped cells with a small oval nucleus were observed. Some of RTL-4 cells, when cultured with 199-10 supplemented with $0.1 \%$ glucose, had a few PAS positive granules, which were digested by amylase.

Electron microscopically, most of RTL-4 cells were large and round with a round nucleus having an extensive electron-dense nucleolus and smooth cell surface with poorly developed microvilli (Fig. 6). Some of these cells had expanded well-developed rough surfaced endoplasmic reticulum (rER) and mitochondria (Fig. 7). A few cells with an elongated nucleus often deeply indented and well-developed microvilli on cell surface. In the cytoplasm of those cells, numerous ribosomes were observed but other intracytoplasmic organella were poorly developed.

\section{Susceptibility to Viruses}

Infectivities of two salmonid fish viruses, IPNV and IHNV, were compared on two cells, RTL-4 and SE-A10, using plaque assay method. Plaques were observed in both cell cultures on the 8th day of IPNV inoculation (Fig. 8A). As shown Table 2 , the titer of the virus were $2.9 \times 10^{8}$ plaque forming units (PFU) per $\mathrm{m} l$ on SE-A10 cells and $-1.7 \times 10^{6} \mathrm{PFU} / \mathrm{m} l$ on RTL- 4 cells, respectively. RTL-4 cells had the slightly low susceptibility to IPNV. The appearance of the cytopathic effects (CPE) of IPNV-infected RTL-4 cells was similar to those in SE-A10 cells with narrow and elongated cell shape and picnotic nuclei.
Plaques formed on IHNV-infected cells were observed at the 8th day on SE-A10 cells and at the 10th day on RTL-4 cells (Fig. 8B) of virus inoculation, respectively. The titer of IHNV were $1.8 \times 10^{6} \mathrm{PFU} / \mathrm{ml}$ on SE-A10 cells and $1.5 \times$ $10^{5} \mathrm{PFU} / \mathrm{m} l$ on RTL-4 cells (Table 2). RTL-4 cells had a tenth or less sensitivity to IHNV than that of SE-A10 cells. The morphology of the CPE of IHNV in RTL-4 cells was as same as that of SE-A10 cells, characterized with round-shaped cells and thickened nuclear membrane.

\section{Discussion}

The liver cells transferred from rainbow trout fry into tissue culture flasks multiplied very slowly and took 40 days even in the RTL-4 flask to form a confluent cell sheet. And, in only two flasks of seven flasks, epithelial cells have dominantly grown. RTL-4, one of them, grew with comparative rapidity and was transferable. Many works have been performed to culture liver cells with differentiated hepatic functions using mammalian hepatocytes. ${ }^{13-15)}$ Recently, many growth factors have been found and isolated from mammalian tissues $(16,17$ : for recent reviews). EGF and insulin or insulin-like growth factors are known to be effective on the DNA synthesis and cell growth of liver cell culture. ${ }^{14)}$ In our study, though only seven experiments were performed, epithelial cells grew and have been subcultured for 40 times in a medium supplemented with EGF and insulin. It is suggestive that mammalian growth factors and hormones which stimulate the growth of mammalian cells have also mitogenic effects for epithelial cells from fish tissue. But, we could not detect EGF receptor on the surface of RTL-4 cells nor rainbow trout hepatocytes (data was not shown), though many mammalian cell lines have EGF receptor. ${ }^{18}$ ) Further investigations are required to examine the effect of growth factors on lower vertebrate cells and presence of receptor to this growth factor, because EGF receptor has close similarity in amino acid sequences to avian oncogene protein. ${ }^{19)}$

There is no evidence to indicate directly that RTL-4 cells have the properties of fish hepatocytes. The morphology of the cells does not resemble hepatic parenchymal cells. Electron microscopical study gives us an expectation that RTL-4 cells may be derived from hepatocytes. The cells also have an ability to store glycogen, one of the important properties of hepatocytes. 
RTL-4 cells have low susceptibility to IHNV of which targets are hematopoietic cells. And the cells have high susceptibility to IPNV of which targets are known to be epithelial cells with well developed rER such as hepatocytes because the virus uses rER for its replication. ${ }^{11}$ These data suggest the possibility that the cells are derived from hepatocytes, but transformed to adapt the in vitro condition and resulted in morphological change. The cytochemical and enzymological examinations on RTL-4 cells are under experiment to clarify whether the cells are hepatocytes or not.

The authors are grateful to Mr. N. Hasegawa, Yamaguchi Trout Farm, who supplied them fish, and, Miss Y. Nakayama and Miss A. Kimura, for their technical assistances.

\section{References}

1) K. Wolf and J. A. Mann: In Vitro, 16, 168-179 (1980).

2) K. Wolf and M. C. Quimby: Science, 135, 10651066 (1962).

3) M. Namba, F. Hyodo, and T. Kimoto: in "Nutritional Requirements of Cultured Cells" (ed. by H. Katsuta), Jap. Sci. Soc. Press, Tokyo, 1978, pp. 277-291.

4) J. Morrow: Eukaryotic Cell Genetics, Academic Press, New York, 1983, pp. 99-112.

5) S. Hayashi and Z. Ooshïro: Nippon Suisan Gakkaishi, 51, 765-771 (1985).

6) R. A. Richman, T. H. Claus, S. J. Pilkis, and D. L. Friedman: Proc. Natl. Acad. Sci. USA,
73, 3589-3593 (1976).

7) T. Watanabe, M. Sano, Y. Ishida, Y. Mizusawa, and M. Michikawa: Nippon Suisan Gakkaishi, 46, 1203-1209 (1980).

8) H. Asakawa, Y. Tsuda, M. Sukegawa, M. Nakano, T. Moritomo, and T. Watanabe: Bull. Coll. Agr. Vet, Med., Nihon Univ., 43, 188-193 (1986) (in Japanese).

9) K. Wolf, S. F. Sniesko, C. E. Dunber, and E. Pyle: Proc. Soc. Exp. Biol. Med., 104, 105-108 (1960).

10) D. F. Amend, W. T. Yasutake, and R. W. Mead: Trans. Am. Fish. Soc., 98, 796-804 (1969).

11) T. Watanabe, K. Tanaka, O. Tamura, Y. Nakagawa, and K. Takahashi: Nippon Suisan Gakkaishi, 46, 401-406 (1980).

12) J. C. Leong, J. L. Fendrick, S. Youngman, and A. Lee: J. Fish Dis., 4, 335-344 (1981).

13) T. H. Claus, S. J. Pilkis, and C. R. Park: Biochim. Biophys. Acta., 404, 110-123 (1975).

14) R. A. Richman, T. H. Claus, S. J. Pilkis, and D. L. Friedman: Proc. Natl. Acad. Sci. USA, 73, 3589-3593 (1976).

15) C. Guguen-Gulllouzo and A. Guillouzo: $\mathrm{Mol}$. Cel. Biochem., 53/54, 35-56 (1983).

16) G. Guroff: Growth and Maturation Factors, Vol. 1, Wiley, New York, 1983.

17) W. L. Mckeehan: Nature, 321, 629-630 (1986).

18) H. T. Haigler: in "Growth and Maturation Factors, Vol. 1" (ed. by G. Guroff), Wiley, New York, 1983, pp. 117-154.

19) T. Downward, Y. Yarden, E. Mayes, G. Scrace, N. Totti, P. Stockwell, A. Ullrich, J. Schlessinger, and M.D. Waterfield: Nature, 307, 521-527 (1984). 